\title{
Analytical and microscopical studies on the protective effect of ascorbic acid (vitamin $C$ ) and beta-carotene against the toxicity induced by fenitrothion on the liver of female albino rats
}

\author{
* Ekram F. Hashim and Kadry Weshahy \\ * Department of Plant Protection, Faculty of Agriculture, Cairo University, Fayoum, Egypt . \\ ** Department of Plant Protection, Faculty of Agriculture, Ain Shams University, Cairo, Egypt
}

\begin{abstract}
The organophosphate insecticide feneitrothion is a contact insecticide and selective acaricide. It is used as a fly, mosquito and cockroach, residual contact spray for farms and public health programs.

The objectives of the present study were to evaluate the toxicity of fenitrothion on the female rate and the possible protective effects of ascorbic acid (vitamine $\mathrm{C}$ ) and beta-carotene as antioxidant agents against the toxicity induced by fenitrothion. Sixty of adult female albino rats were randomly assigned to six equal groups including control group and groups treated orally with ascorbic acid (10mg/kg b.w.), beta-carotene (10mg / $\mathrm{kg}$ b.w.) with or without fenitrothion $\left(15.65 \mathrm{mg} / \mathrm{kg}\right.$ b.w. i.e $\left.1 / 16 \mathrm{LD}_{50}\right)$ for 28 successive days.

Ingestion of fenitrtothion caused a significant increase in ALT (alanine transferase), AST (aspartate transferase), and AP (alkaline phosphatase). It decreased signifiantly GL (glucose) level, AchE (acetyle cholinesterase) and GSH (glutathion reductase) activities, while, it had insignificant effects on TB (total bilirubine) and a slight decrease in TP (total protein). The histological study of female rat liver tissues by Hx \& Eosin,P.A.S, and Methyl Green Pyronine revealed that, fenitrothion showed vascular and degenrative changes in the hepatic cells, Also, it caused a significant decrease in glycogen contents and depletion in of nucleic acids in hepatic cells.

Treatments with ascorbic acid and beta-carotene plus fenitrothion hasn't been caused any significant changes in all parameters in serum of female rats. Treatment with ascorbic acid plus fenitrothion resulted a significant improvement in all parameters tested regarding to the histological study, while, beta-carotene plus fenitrothion showed the same improvement except in glycogen content in hepatic cells .

Key Words : Fenitrothion - Toxicity - ALT - AST - GL - AChE - Rats - Histological - beta - carotene - Ascorbic acid .
\end{abstract}




\section{Analytical and microscopical studies}

\section{Introduction}

The immense increase in agricultural productivity which has occurred since world war II owns much to the introduction of synthetic pesticides. The powerful insecticidal properties of the organophsphorous compounds promoted their widespread use for the control of agricultural pests and invertebrate vector of animals and human disease. Unfortunately, the problems of residual toxicity has led to significant damage to many ecosystems and concern that their presence in all types of food might present a carcino genic hazard to man (Concon, 1988) .

The organophosphate insecticide fenitrothion is a contact insecticide and selective acaricide of low ovicidal properties. It may also be used as a fly, mosquito, and cockroach residual contact spray for farms and public health programs [Worthing, 1983]. In the last years, the using of organophosphate insecticide in Egypt was increased; humans and non-target organisms are exposed to these pesticides, via food, water, and air. There is much toxicological effect due to the chemical. Fenitrothion is greater acetylcholin esterase (AChE) inhibitor than Malathion (Berber et al 1999) .

Manisha et al (1999), reported that organophosphates had been shown to produce oxidative stress through the generation of free oxygen radicals. Dwivedi et al (1998), found that the hepatic antioxidant defense system, glutathion reductase (GSH). Comprising catalase and GSH peroxidase significantly increased in OP treated animals .

Hai et al (1995), reported that dichlorvos exposure significantly decreased glutathion peroxidase activity and has an inhibitory effect on acetylcholinsterase and induced changes characteristic of oxidative stress.

$$
\text { Lukaszewicz et al (1999), }
$$
concluded that the changes in antioxidant enzyme activities and malondialdehyde concentration in the blood indicate hypoxia in the first period of intoxication (within 24 hours) and reoxidation in the later period. Early studies have been shown that an antioxidant has a direct effect on oxygen free radicals, which caused lipid peroxidant in the liver and also glutathion (GSH) precursor (Sen, 1999).

L-Ascorbic acid (Vitamin C) occurs widly in nature. Its use as oxygen scavengers and also as synergists in a wide variety of food products .

Ascoribic acid had been allocated an ADI "not limited" by the JECFA (FAO / WHO, 1981).

Stevenson et al (1995) concluded that, the ability of antioxidant (ascorbic acid) vitamin $C$ and vitamin $E$ to inhibit dieldrin - induced DNA synthesis suggested oxidative stress involved in the toxicity of this insecticides, while, the inability of these vitamins to prevent all hepatotoxic changes indicate other factors are also involved. Geetanjali et al, (1993) supported the protective role of ascorbic acid against the organophosphate dimethoate .

Beta-carotene (provitamin A) is mainly used as food colornate. It is effective quenchers of singlet oxygen and can act as antioxidants by preventing the formation of hydro peroxides . It is not toxic to rats, dogs and humans . An ADI of $0.5 \mathrm{mg} / \mathrm{kg}$ b. w. bas been allocated by the GECFA (FAO / WHO, 1974) .

Salem et al. (1995), found that organophosphorus compounds toxicity 
caused many degenerative and necrotic changes in the blood vessels as well as in the liver, lungs, kidney, intestines testicles, and siatic nerve. Also, they found that, the use of antioxidant vitamins A., D, E prove to be beneficial in over coming and minizing the pathological action of phospholan toxicity .

Minakata, et. al. (1995), found that, plasma component revealed appreciable changes in the concentrations of an acute - phase reactant protein and some vitamins that act as antioxidant, vitamin $\mathrm{C}$ and its radical increased by 1-5 and 1-7 fold of the control, repestively after treatment of paraquat .

Do et al (1997), reported that, the inhibitory effect of organophosphate insecticide -dichlorvos- on acetylcholine esterase, induced changes Characteristic of oxidative stress .

Nabila et al (2001), reported that, treatment with antioxidant cystein or green tea plus pyriproxyfen showed a significant protective effect in the parameters of liver kidney functions regarding the biochemical, histolgical and histochemical studies.

The objectives of the present study were to evaluate the protective effect of the antioxidants ascorbic acid (vitamin $\mathrm{C}$ ) and beta-carotene against toxicty induced by the insecticide fenitrothion on female rats.

Kadry et al (2001) reported that, fenitrothion showed significant inhibition in the ACHE and glutationeS-transferase (GST) activities after exposure while AST, ALT, TB, creatinine and urea exhibited general significant elevation compared with the control values .

\section{Materials and Methods}

Materials:

Fenitrothion,[o,o-dimethylo-(3 -methy 1 - 4 - nitrophenyl) phosphorothioate] (Fig. 1) was purchased in the form of emulisifiable concentrate formulation (50 EC) from Sumitomo Chemical Co. (Osaka)-Japan. The orally $\mathrm{LD}_{50}$ of fenitrothion was determined according to Finney (1952). The selected dose was $15.65 \mathrm{mg} \mathrm{/} \mathrm{kg}$ of body weight (equivalent of $1 / 16$ of $\mathrm{LD}_{50}$ ).

Fig (1): Fenitrothion .

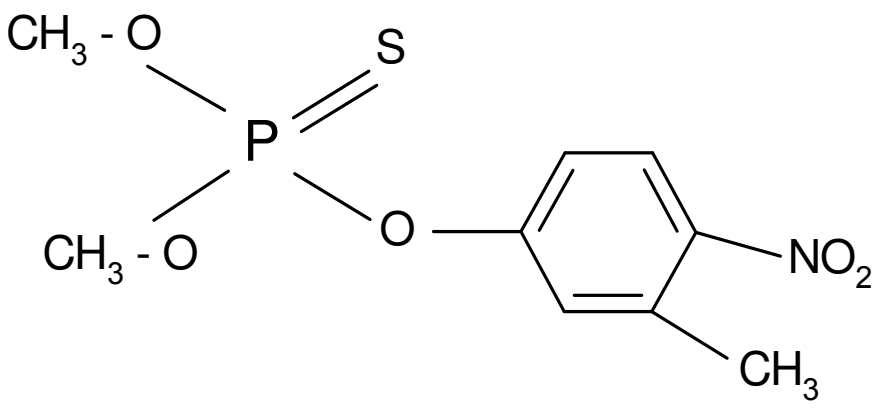

L-Ascorbic acid (vitamin C), 3-keto-1-glucofur- anolactone (Fig. 2) was obtained in from of tablets from Memphis Co. Pharm. \& Chemical Ind . (Cairo - A.R.E.). 


\section{Analytical and microscopical studies}

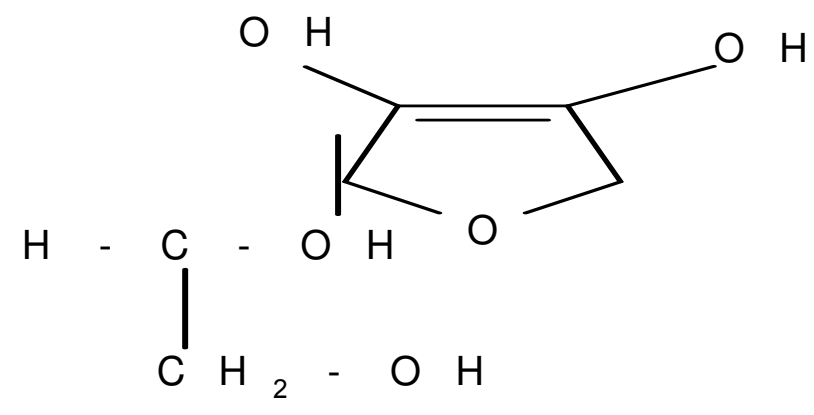

Fig (2) : L-Ascorbic acid

Beta-carotene (provitamin A) (Fig. 3) was purchased from Memphis Co. Pharm. \& Chemical Ind. (Cairo - A. R. E.)

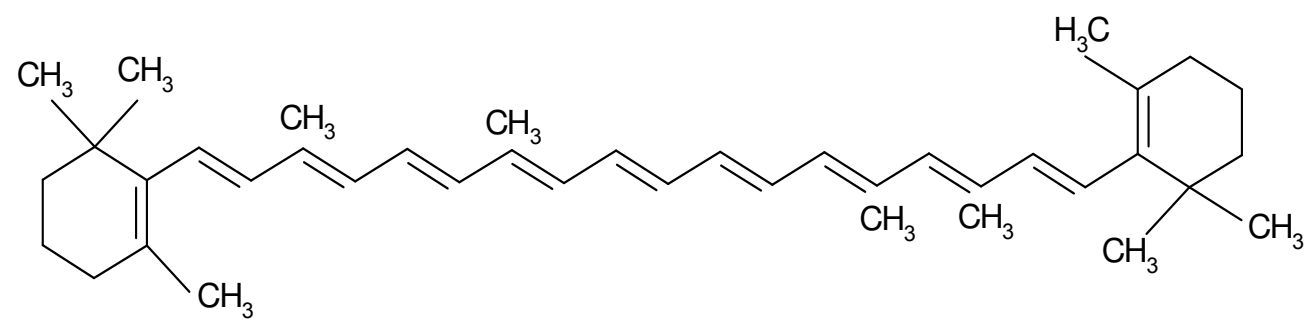

Fig (3): Beta-carotene

\section{a-Animals :}

Three months old, sexually mature female albino rats (derived from spragu - Dawley) weighing $150 \pm 10 \mathrm{~g}$ were purchased from animal house colony, Giza, Egypt. The animals were maintanined on standard laboratory diet (protein : 16-04\%; Fat : 3,63; Fiber : $401 \%$ and metabolic energy : $2887 \mathrm{kcal}$, $\mathrm{kg}$ ) and water ad libitum for one week to aclimatize under the laboratory conditions, temp. $\left(27 \pm 3^{\circ} \mathrm{C}-60 \pm 5 \mathrm{RH}\right)$. After axclimatization period, animals were divided into six groups (10 rats / group) and housed in glass cages $(65 \mathrm{x}$ $70 \times 20 \mathrm{~cm})$.

Experimental animals were given orally daily for 28 successive days; group 1, untreated control; group 2, were given orally fenitrothion (15.65 $\mathrm{mg} / \mathrm{kg} \mathrm{b.w)}$ equivalent $1 / 16$ of $\mathrm{LD}_{50}$ ); group 3, were given orally fenitrothion plus beta-carotene (10 mg / $\mathrm{kg} \mathrm{b.w)}$ group 4, were given fenitrothion plus ascorbic acid with the same doses, group 5, were given ascorbic acid (vitamin C) (10 mg / kg b.w); group 6, were given orally beta-carotene $(10 \mathrm{mg} /$ kg b.w) .

The doses were given at similar times each day, and adjusted as necessary to maintain its constant serum level in for body weight. During the period of administration, the animals were observed closely, each day for signs of toxicity .

After the end of the treatment period, blood samples were collected from rat tail veins and kept in heparinized tubes for biochemical analysis. 


\section{Biochemical analysis :}

Acetyl cholinesterase (AChE) activity was determined in serum samples using $0.1 \mathrm{M}$ phosphate buffer, $\mathrm{pH} 7.2$ and acetylthiocholin iodide as substrate, according to the method of Ellman et al., (1961). Alanine transferase (ALT) and aspartate transferase (AST) were determined in serum according to the method described by Reitman and Frankel (1957). Total bilirubin (TB) was determined according to the method of Pearlman and Lee (1971) .

Alkaline phosphatase (AP) and glulathion reductase (GSH) were determined in serum samples using 0.1 $\mathrm{M}$ carbonate buffer, $\mathrm{pH} 10.2$ and diphenyl phosphate as substrate for (AP) and $0.2 \mathrm{M}$ sodium phosphate buffer, $\mathrm{pH} 7.2$ and 1-chloro-2,4dinitrobenzene (CDNB) as a substrate for (GSH) according to the method of Powell and smith, (1954) and Habig et al. (1974), respectively. Also, total protein (TP) and surum glucose (GL) were determined according to the method of Bradford (1976) and Trinder (1969), respectively .

\section{Histological studies :}

All animals were sacrificed and dissected on day 28 , livers, were exised and fixed in $10 \%$ neutral formalin. Paraffin sections of 7 micrometer thickness were prepared and stained by $\mathrm{Hx}$ and Eosin for morphological study (Drury and Wallington, 1980). P.A.S. (Pearse, 1968) to demonstrate glycogen content and Methyl Green Pyronin (Clayden, 1971) for nucleic acid content.. Sections stained with PAS were subjected to analysis by using the image analyzer (Lecica image analyzer) and the obtained data were tabulated and statistically analyzed..

\section{Statistical analysis :}

All data were subjected to statistical analysis under standing Medical statistical methods by Leonard (1983)

\section{Results}

Biochemical analysis :

Effects of antioxidants [i.e. ascorbic acid (10 $\mathrm{mg} / \mathrm{kg} \mathrm{b.w)]} \mathrm{and}$ [beta-carotene $(10 \mathrm{mg} / \mathrm{kg} \mathrm{b.w})$ ] as protectors and insecticide fenitrothion $(15.65 \mathrm{mg} / \mathrm{kg} \quad$ b.w $)$ on serum biochemical analysis of female rats were studied .

Data in Table (1) and Fig. (4), showed that, oral administration with fenitrothion alone (15.65 mg / kg b.w) resulted a significant increase in aspartate transaminase (AST) activity compared with control (P. <0.05) .

Treatment with fenitrothion plus ascorbic acid compared with fenitrothion alone resulted in a significant decrease in the level of AST in blood ( $\mathrm{P}$. value $<0.05)$, however, treatment with fenitrothion plus betacarotene compared with fenitrothion alone resulted in a significant decrease in level of AST in blood $(\mathrm{P}<0.05)$.

Treatment with ascorbic acid alone compared with control specimens resulted in significant increase in the level of AST in blood ( $\mathrm{P}$ value $<0.05$ )

Treatment with beta-carotene alone compared with control specimens resulted in a significant increase in the level of AST in blood (P. < 0.05) .

Data in Table (2) and Fig. (5), showed that, oral administration with fenitrothion alone resulted in a significant increase in alanine transaminase (ALT) activity in blood when compared with control group $(\mathrm{P}<$ $0.05)$. 


\section{Analytical and microscopical studies}

Treatment with fenitrothion plus ascorbic acid compared with significant decrease in the level of ALT fenitrothion alone resulted in a

Table (1): Effect of fenitrothion alone and in combination with ascorbic acid and beta-carotene on AST activity in female rats.

\begin{tabular}{|c|c|c|c|c|c|c|}
\hline Parameter & Control & Fenitrothion & $\begin{array}{l}\text { Fenitro+ascorbic } \\
\text { acid }\end{array}$ & Fenitro.+beta carotene. & ascorbic acid & beta carotene \\
\hline \multirow{3}{*}{$A S T(U / L)$} & 26 & 43.33 & 11.67 & 26 & 22.33 & 29 \\
\hline & 17 & 30 & 17 & 36.33 & 25.33 & 30 \\
\hline & 17.33 & 26.67 & 12 & 18.33 & 26 & 27 \\
\hline Mean & 20.11 & 33.33 & 13.56 & 26.89 & 24.55 & 28.67 \\
\hline S.D. & 5.10 & 8.82 & 2.99 & 9.03 & 1.95 & 1.53 \\
\hline Gr.comp. & & C:Fenitro & $\begin{array}{c}\text { Fenitro:F.+ascorbic } \\
\text { acid }\end{array}$ & Fenitro:F.+beta carotene & C:ascorbic acid & $\begin{array}{l}\text { C:beta } \\
\text { carotene }\end{array}$ \\
\hline T.Value & & 0.0146 & 0.1467 & 0.2180 & 0.1939 & 0.0503 \\
\hline$P$ value & & $<0.05$ & $<0.05$ & $<0.05$ & $<0.05$ & $<0.05$ \\
\hline Signif. & & Sig. inc & Sig.dec & Sig.dec & Sig. inc & Sig. inc \\
\hline
\end{tabular}

Fig. (4): Effect of fenitrothion alone and in combination with ascorbic acid and betarotene on AST activity in female rats

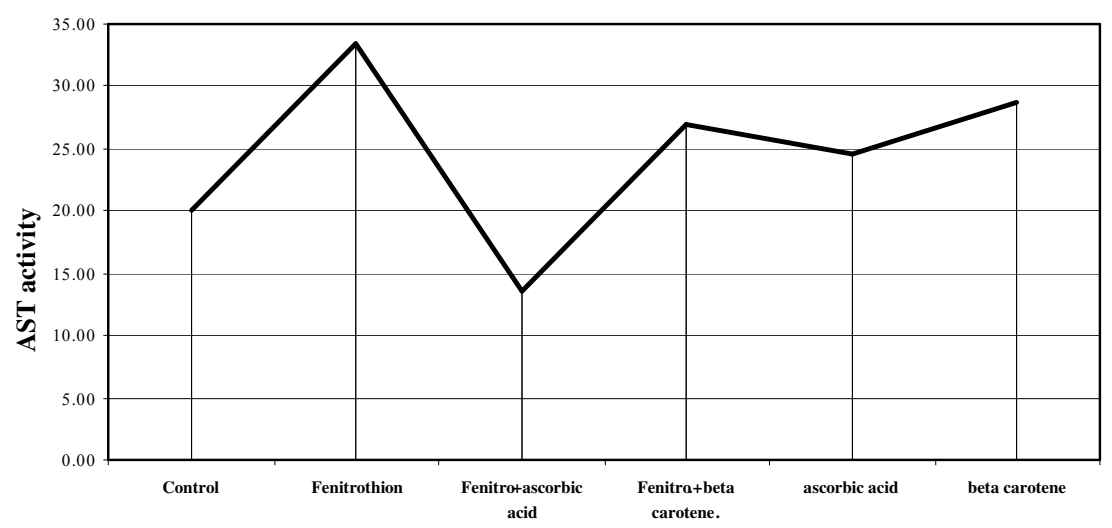


Ekram F. Hashim and Kadry Weshahy

Ta ble (2): Effect of fenitrothion alone and in combination with ascorbic acid and beta-carotene on ALT activity in female rats.

\begin{tabular}{|c|c|c|c|c|c|c|}
\hline Parameter & Control & Fenitrothion & Fenitro+ascorbic acid & Fenitro.+beta carotene. & ascorbic acid & beta carotene \\
\hline \multirow{3}{*}{$A L T(U / L)$} & 20.67 & 34.6 & 22.66 & 19.67 & 12.83 & 24.5 \\
\hline & 13.67 & 21.67 & 13.66 & 27.5 & 21.5 & 17.67 \\
\hline & 15.5 & 24.66 & 21.67 & 24.67 & 17 & 24.5 \\
\hline Mean & 16.61 & 26.98 & 19.33 & 23.95 & 17.11 & 22.22 \\
\hline S.D. & 3.63 & 6.77 & 4.94 & 3.96 & 4.34 & 3.94 \\
\hline Gr.comp. & & C:Fenitro & Fenitro:F.+ascorbic acid & $\begin{array}{c}\text { Fenitro:F.+beta } \\
\text { carotene. }\end{array}$ & C:ascorbic acid & C:beta carotene \\
\hline \multirow[t]{3}{*}{ T.Value } & & 0.0147 & 0.1298 & 0.1211 & 0.4615 & 0.0402 \\
\hline & & $<0.05$ & $<0.05$ & $<0.05$ & $<0.05$ & $<0.06$ \\
\hline & & Sig. inc & Sig.dec & Sig.dec & Sig. inc & Sig. inc \\
\hline
\end{tabular}

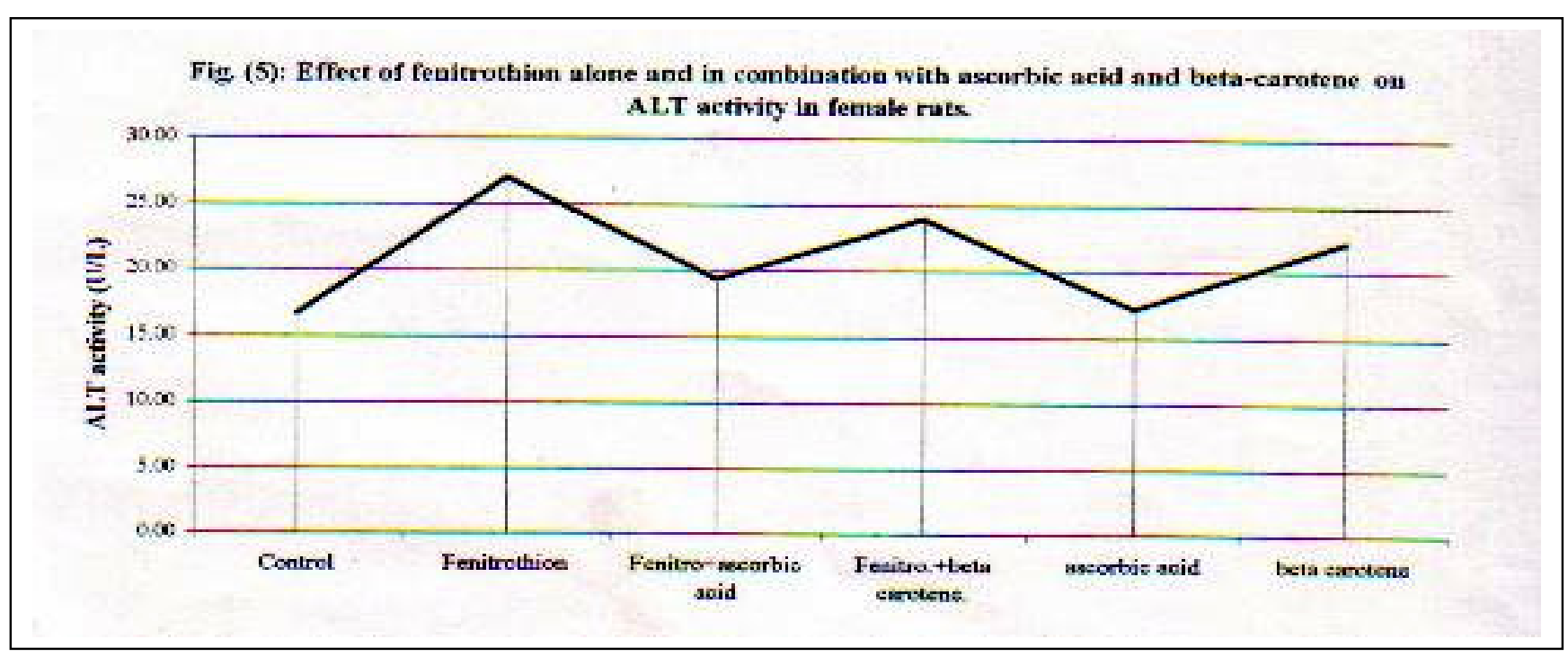

Treatment with fenitrothion plus beta-carotene compared with fenitro thion alone caused a significant decre ase in level of ALT in blood $(\mathrm{P}<0.05)$.

Treatment with ascorbic acid alone compared with control caused in a significant increase in the level of ALT in blood $(\mathrm{P}<0.05)$.

Treatment with beta-carotene alone compared with control specimens resulted in a significant increase in the level of ALT in blood $(\mathrm{P}<0.05)$. 


\section{Analytical and microscopical studies}

Also, the data in Table (3) and Fig. (6), showed a significant decrease in serum glucose (GL) content with control $(\mathrm{P}<0.05)$.

Treatment with fenitrothion plus ascorbic acid compared with fenitrothion alone resulted in a significant increase in glucose level in blood when compared with control group $(\mathrm{P}<0.05)$.

Treatment with fenitrothion plus beta-carotene compared with fenitrothion alone resulted in a significant increase in level of glucose in blood $(\mathrm{P}<0.05)$.

Treatment with ascorbic acid alone compared with control caused a significant decrease in the level of blood glucose $(\mathrm{P}$ value $<0.05)$.

Treatment with beta-carotene alone compared with control specimens resulted in a significant decrease in the level of blood glucose $(\mathrm{P}<0.05)$.

In Table (4) and Fig. (7), the date showed a significant increase in Total bilirubin (TB) content with fenitrothion alone compared with control $(\mathrm{P} .<0.05)$

Treatment with fenitrothion plus ascorbic acid compared with fenitrothion alone resulted in a significant decrease in total bilirubine (TB) level in blood when compared with control $(\mathrm{P}<0.05)$.

Table (3): Effect of fenitrothion alone and in combination with ascorbic acid and beta-carotene on glucose (GL) level in female rats.

\begin{tabular}{|c|c|c|c|c|c|c|}
\hline Parameter & Control & Fenitrothion & Fenitro+ascorbic acid & Fenitro.+beta carotene. & ascorbic acid & beta carotene \\
\hline \multirow{3}{*}{$\begin{array}{l}\text { Glucose } \\
\text { (mg/dl) }\end{array}$} & 104.58 & 60.17 & 97.58 & 101.55 & 97.46 & 96.27 \\
\hline & 121.7 & 51.36 & 104.31 & 95.95 & 72.04 & 90.68 \\
\hline & 115.33 & 55.09 & 94.59 & 93.58 & 89.75 & 85.92 \\
\hline Mean & 113.87 & 55.54 & 98.83 & 97.03 & 86.42 & 90.96 \\
\hline S.D. & 8.65 & 4.42 & 4.98 & 4.09 & 13.03 & 5.18 \\
\hline Gr.comp. & & C:Fenitro & Fenitro:F.+ascorbic acid & Fenitro:F.+beta carotene. & C:ascorbic acid & C:beta carotene \\
\hline T.Value & & 0.0082 & 0.0134 & 0.0024 & 0.0778 & 0.0443 \\
\hline$P$ value & & $<0.05$ & $<0.05$ & $<0.05$ & $<0.05$ & $<0.06$ \\
\hline Signif. & & Sig.dec & Sig. inc & Sig. inc & Sig.dec & Sig.dec \\
\hline
\end{tabular}


Ekram F. Hashim and Kadry Weshahy

Fig. (6): Effect of fenitrothion alone and in combination with ascorbic acid and betacarotene on glucose (GL) level in female rats

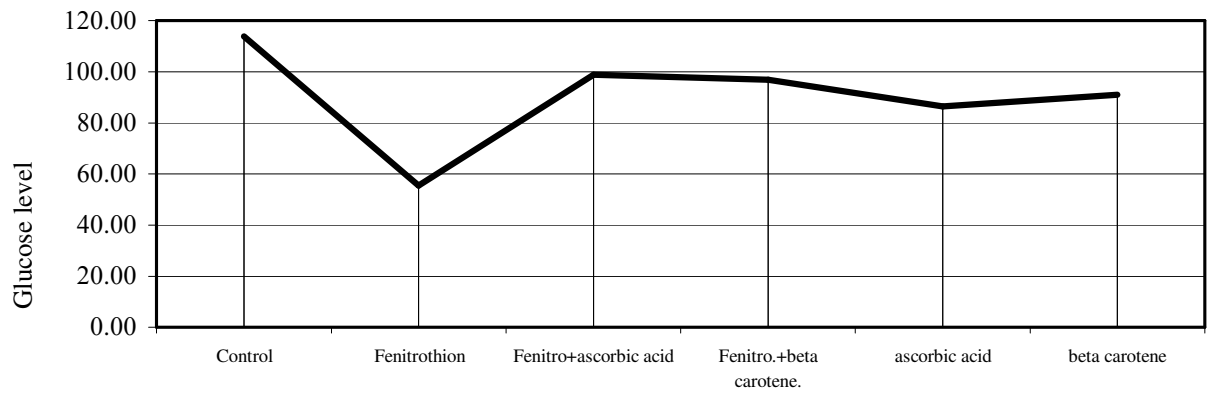

Table (4): Effect of fenitrothion alone and in combination with ascorbic acid and beta-carotene

on total bilirubine (TB) in female rats.

\begin{tabular}{|c|c|c|c|c|c|c|}
\hline Parameter & Control & Fenitrothion & Fenitro+ascorbic acid & Fenitro.+beta carotene. & ascorbic acid & beta carotene \\
\hline \multirow[t]{3}{*}{$T . B(m g / d l)$} & 1.5 & 1.51 & 1.29 & 1.4 & 0.69 & 1.32 \\
\hline & 1.18 & 1.33 & 1.03 & 1.58 & 1.32 & 1.03 \\
\hline & 1.33 & 1.26 & 1.57 & 1.85 & 1.1 & 1.57 \\
\hline Mean & 1.34 & 1.37 & 1.30 & 1.61 & 1.04 & 1.31 \\
\hline S.D. & 0.16 & 0.13 & 0.27 & 0.23 & 0.32 & 0.27 \\
\hline Gr.comp. & & C:Fenitro & Fenitro:F.+ascorbic acid & Fenitro:F.+beta carotene. & C:ascorbic acid & C:beta carotene \\
\hline T.Value & & 0.3433 & 0.1580 & 0.3898 & 0.1956 & 0.4225 \\
\hline$P$ value & & $<0.05$ & $<0.05$ & $<0.05$ & $<0.05$ & $<0.06$ \\
\hline Signif. & & Sig. inc & Sig.dec & Sig. inc & Sig.dec & Sig.dec \\
\hline
\end{tabular}

Fig. (7): Effect of fenitrothion alone and in combination with ascorbic acid and beta-carotene on total bilirubine (TB) in female rats.

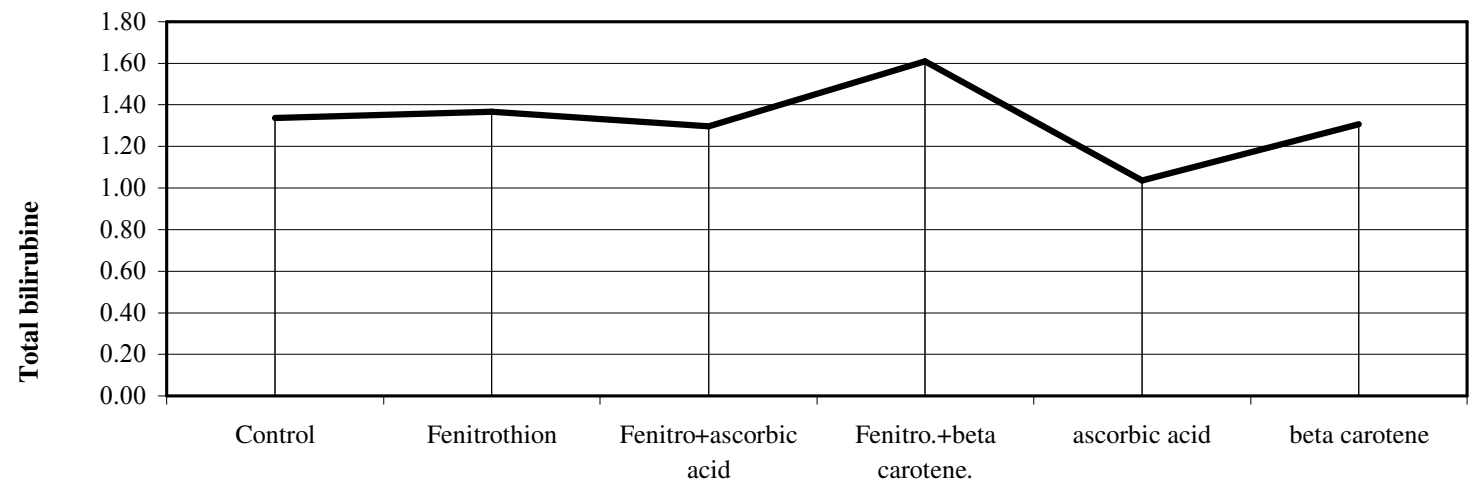




\section{Analytical and microscopical studies}

Treatment with fenitrothion plus beta-carotene compared with fenitro thion alone caused a significant decr ease in the activity of AP in blood $(\mathrm{P}<$ $0.05)$.

Treatment with ascorbic acid alone compared with control caused in a significant increase in the activity of AP in blood ( $\mathrm{P}$ value $<0.05)$.

Treatment with beta-carotene alone compared with control specimens results in a significant increase in the activity of AP in blood $(\mathrm{P}<0.05)$.

Data in Table (6) and Fig. (9), showed that, oral administration with fenitrothion alone resulted in a significant decrease in total protein (TP) content in blood when compared with control group ( $\mathrm{P}$ value $<0.05)$.

Treatment with fenitrothion plus ascorbic acid compared with fenitro thion alone resulted in a significant increase in the activity of TP in blood ( $\mathrm{P}$ $<0.05)$.
Treatment with fenitrothion plus beta-carotene compared with fenitrot hion alone resulted in a significant increase in level of TB in blood $(\mathrm{P}<$ $0.05)$.

Treatment with ascorbic acid alone compared with control group caused a significant decrease in the level of blood TB $(\mathrm{P}<0.05)$.

Treatment with beta-carotene compared with control group resulted in a significant decrease in TB level in blood (P value $<0.05)$.

The data in Table (5) and Fig. (8), showed that, oral administration with fenitrothion alone resulted in a signific ant increase in alkaline phosphatase (AP) activity in blood when compared with control group $(\mathrm{P}<0.05)$.

Treatment with fenitrothion plus ascorbic acid compared with fenitrot hion alone resulted in a significant decrease in the activity of AP in blood $(\mathrm{P}<0.05)$.

Table (5): Effect of fenitrothion alone and in combination with ascorbic acid and beta-carotene on alkaline phosphatase (AP) activity in female rats.

\begin{tabular}{|c|c|c|c|c|c|c|}
\hline Parameter & Control & Fenitrothion & Fenitro+ascorbic acid & Fenitro.+beta carotene. & ascorbic acid & beta carotene \\
\hline \multirow[t]{3}{*}{$A P \quad U / L$} & 28.32 & 145.4 & 27.3 & 32.7 & 49.16 & 43.18 \\
\hline & 27.27 & 147.2 & 25 & 41.3 & 38.01 & 44.8 \\
\hline & 31.1 & 120.5 & 26.9 & 59 & 41.1 & 58.2 \\
\hline Mean & 28.90 & 137.70 & 26.40 & 44.33 & 42.76 & 48.73 \\
\hline S.D. & 1.98 & 14.92 & 1.23 & 13.41 & 5.76 & 8.24 \\
\hline Gr.comp. & & C:Fenitro & Fenitro:F.+ascorbic acid & Fenitro:F.+beta carotene. & C:ascorbic acid & C:beta carotene \\
\hline T.Value & & 0.0040 & 0.0041 & 0.0109 & 0.0291 & 0.0167 \\
\hline$P$ value & & $<0.05$ & $<0.05$ & $<0.05$ & $<0.05$ & $<0.06$ \\
\hline Signif. & & Sig. inc & Sig.dec & Sig.dec & Sig. inc & Sig. inc \\
\hline
\end{tabular}


Ekram F. Hashim and Kadry Weshahy

Fig. (8): Effect of fenitrothion alone and in combination with ascorbic acid and beta

-carotene on alkaline phosphatase (AP) activity in female rats.

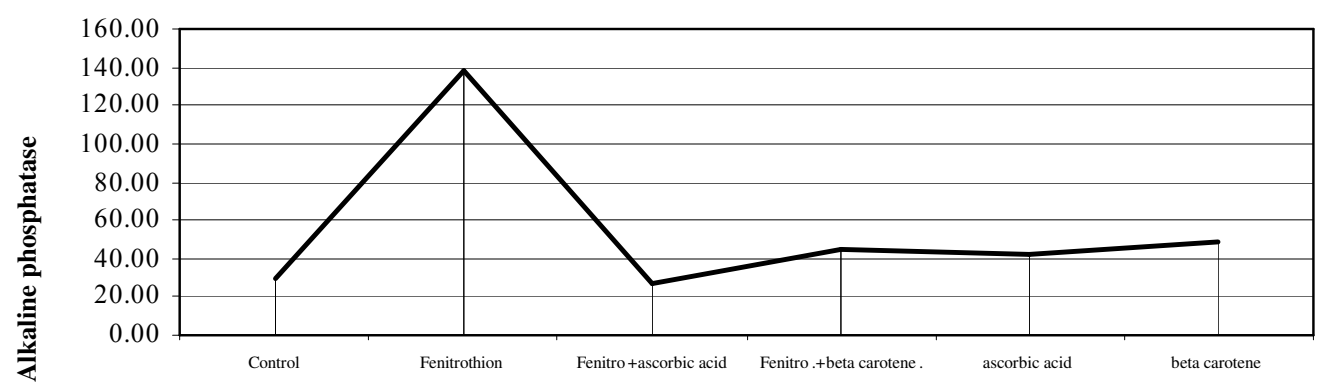

Table (6): Effect of fenitrothion alone and in combination with ascorbic acid and beta-carotene on total protein (TP) in female rats.

\begin{tabular}{|c|c|c|c|c|c|c|}
\hline Parameter & Control & Fenitrothion & $\begin{array}{c}\text { Fenitro+ascorbic } \\
\text { acid }\end{array}$ & $\begin{array}{l}\text { Fenitro.+beta } \\
\text { carotene. }\end{array}$ & ascorbic acid & beta carotene \\
\hline \multirow[t]{3}{*}{$T P(g / d l)$} & 5.47 & 4.57 & 6.31 & 5.06 & 5.34 & 4.56 \\
\hline & 5.85 & 4.7 & 6.76 & 6.76 & 5.77 & 5.47 \\
\hline & 5.37 & 5.01 & 5.74 & 5.74 & 4.93 & 5.07 \\
\hline Mean & 5.56 & 4.76 & 6.27 & 5.85 & 5.35 & 5.03 \\
\hline S.D. & 0.25 & 0.23 & 0.51 & 0.86 & 0.42 & 0.46 \\
\hline Gr.comp. & & C:Fenitro & $\begin{array}{c}\text { Fenitro:F.+ascorbic } \\
\text { acid }\end{array}$ & $\begin{array}{c}\text { Fenitro:F.+beta } \\
\text { carotene. }\end{array}$ & C:ascorbic acid & C:beta carotene \\
\hline T.Value & & 0.0374 & 0.1153 & 0.1935 & 0.0971 & 0.0547 \\
\hline$P$ value & & $<0.05$ & $<0.05$ & $<0.05$ & $<0.05$ & $<0.06$ \\
\hline Signif. & & Sig.dec & Sig. inc & Sig. inc & Sig.dec & Sig.dec \\
\hline
\end{tabular}

Fig (9): Effect of fenitrothion alone and in combination with ascorbuaratidhandhble protei(íT) in female rats

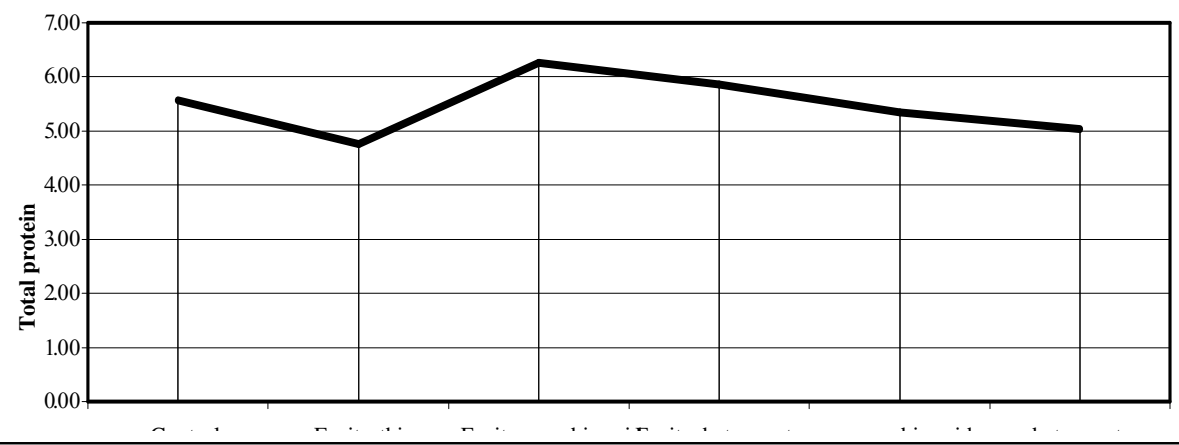




\section{Analytical and microscopical studies}

Treatment with fenitrothion plus betacarotene compared with fenitro -thion alone caused a significant increase in the content of TP in blood $(\mathrm{P}<0.05)$

Treatment with ascorbic acid alone compared with control caused in a significant decrease in the content of $\mathrm{TP}$ in blood $(\mathrm{P}<0.05)$.

Treatment with beta-carotene alone compared with control caused in a significant decrease in the level of TP in blood $(\mathrm{P}<0.05)$.

Data in Table (7) and Fig. (10), showed that, oral administration with fenitrothion alone resulted in a significant decrease in specific activity of AChE (S.A) in blood when compared with control group (P value $<0.05)$.

Treatment with fenitrothion plus ascorbic acid compared with fenitro thion alone resulted in a significant increase in the S.A of AChE in blood (P $<0.05)$.
Treatment with fenitrothion plus beta-carotene compared with fenitro thion alone caused a significant increase in S.A of AChE in blood $(\mathrm{P}<0.05)$.

Treatment with ascorbic acid alone compared with control caused in a significant increase in the S.A of AChE in blood ( $\mathrm{P}$ value $<0.05)$.

Treatment with beta-carotene alone compared with control group results in a significant increase in the S.A of AChE in blood $(\mathrm{P}<0.05)$.

Data in Table (8) and Fig. (11), showed that, significant decrease in specific activity S.A of GSH in blood when compared with control group $(\mathrm{P}<$ $0.05)$.

Treatment with fenitrothion plus ascorbic acid compared with fenitrothion alone resulted in a significant increase in the S.A of GSH in blood $(\mathrm{P}<0.05)$

Table (7): Effect of fenitrothion alone and in combination with ascorbic acid and beta-carotene on specific activity (S.A) of acetyl cholinesterase (AChE) in female rats.

\begin{tabular}{|c|c|c|c|c|c|c|}
\hline Parameter & Control & Fenitrothion & Fenitro+ascorbic acid & Fenitro.+beta carotene. & ascorbic acid & beta carotene \\
\hline \multirow[t]{3}{*}{$\operatorname{AChE}(S . A)^{*}$} & 23.85 & 15.45 & 25.33 & 22.19 & 29.15 & 24.27 \\
\hline & 23.05 & 16.25 & 25.65 & 20.91 & 29.65 & 24.15 \\
\hline & 22.75 & 16.95 & 24.85 & 21.55 & 28.95 & 23.97 \\
\hline Mean & 23.22 & 16.22 & 25.28 & 21.55 & 29.25 & 24.13 \\
\hline S.D. & 0.57 & 0.75 & 0.40 & 0.64 & 0.36 & 0.15 \\
\hline Gr.comp. & & C:Fenitro & Fenitro:F.+ascorbic acid & Fenitro:F.+beta carotene. & C:ascorbic acid & C:beta carotene \\
\hline T. Value & & 0.0057 & 0.0008 & 0.0021 & 0.0020 & 0.0335 \\
\hline$P$ value & & $<0.05$ & $<0.05$ & $<0.05$ & $<0.05$ & $<0.06$ \\
\hline Signif. & & Sig.dec & Sig. inc & Sig. inc & Sig. inc & Sig. inc \\
\hline
\end{tabular}

${ }^{\star}$ S.A : Specific activity (n mole /min./mg protein) 
Ekram F. Hashim and Kadry Weshahy

Fig. (10): Effect of fenitrothion alone and in combination with ascorbic acid and beta-carotene on specific activity (S.A) of acetyl cholinesterase (AChE) in female rats.

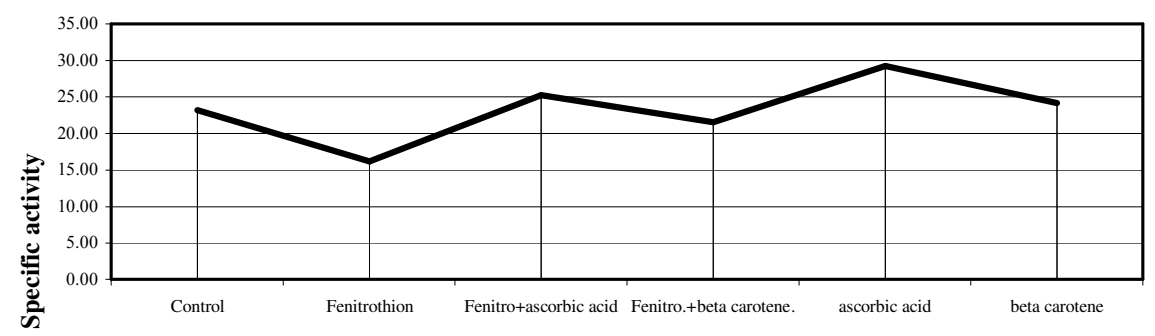

Table (8): Effect of fenitrothion alone and in combination with ascorbic acid and beta-carotene

on specific activity (S.A) of glutathion reductase (GSH) in female rats.

\begin{tabular}{|c|c|c|c|c|c|c|}
\hline Parameter & Control & Fenitrothion & Fenitro+ascorbic acid & Fenitro.+beta carotene. & ascorbic acid & beta carotene \\
\hline \multirow{3}{*}{ GSH $(S . A) *$} & 2.35 & 1.51 & 3.25 & 2.85 & 3.41 & 3.11 \\
\hline & 2.29 & 1.8 & 3.12 & 2.81 & 2.92 & 2.9 \\
\hline & 2.11 & 1.65 & 3.09 & 2.69 & 3.45 & 2.85 \\
\hline Mean & 2.25 & 1.65 & 3.15 & 2.78 & 3.26 & 2.95 \\
\hline S.D. & 0.12 & 0.15 & 0.09 & 0.08 & 0.30 & 0.14 \\
\hline Gr.comp. & & C:Fenitro & $\begin{array}{c}\text { Fenitro:F.+ascorbic } \\
\text { acid }\end{array}$ & Fenitro:F.+beta carotene. & $\begin{array}{l}\text { C:ascorbic } \\
\text { acid }\end{array}$ & C:beta carotene \\
\hline T.Value & & 0.0197 & 0.0112 & 0.0068 & 0.0197 & 0.0022 \\
\hline$P$ value & & $<0.05$ & $<0.05$ & $<0.05$ & $<0.05$ & $<0.06$ \\
\hline Signif. & & Sig.dec & Sig. inc & Sig. inc & Sig. inc & Sig. inc \\
\hline
\end{tabular}

* S.A : Specific activity (n mole /min./mg protein) 
Fig. (11): Effect of fenitrothion alone and in combination with ascorbic acid and beta -carotene on specific activity (S.A) of glutathion reductase (GSH) in female rats .

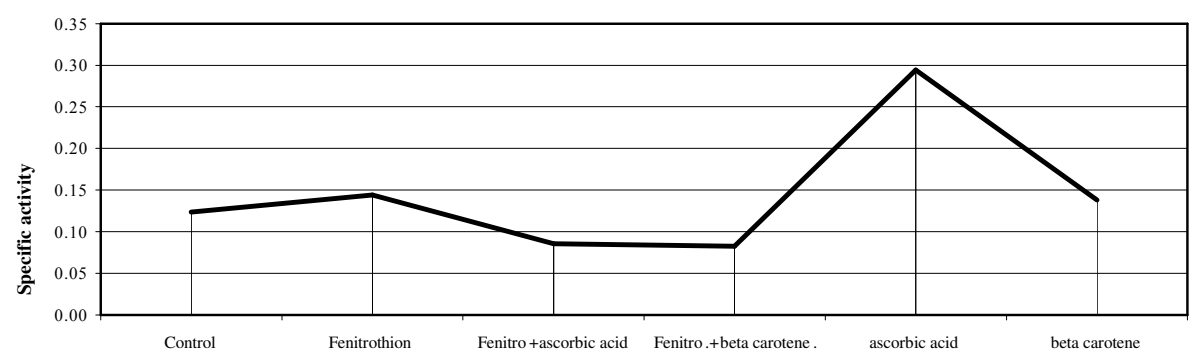

Treatment with fenitrothion plus beta-carotene compared with fenitrothion alone caused a significant increase in S.A of GSH in blood $(\mathrm{P}<$ $0.05)$.

Treatment with ascorbic acid alone compared with control caused a significant increase in S.A of GSH in blood $(\mathrm{P}<0.05)$.

Treatment with beta-carotene alone compared with control specimens resulted in a significant increase in S.A of GSH in blood $(\mathrm{P}<0.05)$.

\section{Histological studies :}

Histological section of the liver of control rat stained with HX and Eosin showed the central vein with radiating hepatic cords (Fig. 12 A). However, after administration of the insecticide fenitrothion there was congestion of the blood vessels of the liver as demonstrated by dilated central vein and hepatic sinusoids with Hemorrhagic areas between the hepatic cells (Fig. 12 B). Moreover, there are evidence of degeneration of hepatic cells in some areas of the hepatic cells (Fig. $12 \mathrm{C}$ ) .

With combination of the insecticide with beta-carotene there is relative decrease or improvement of the vascular dilation without improvement in the degeneration seen in some areas of the hepatic lobules. There are plenty of von kuppfer cells (Fig. 12 D).

On the other hand, combination of the insecticide with ascorbic acid causes relative improvment in the degeneration of the hepatic cells which returns to nearly normal pictures without improvment in the vascular dilatation (Fig. 12 E) .

However, treatment with betacarotene alone causes no vascular or cellular changes in hepatic cells (Fig. 12 F). The same results were obtained with treatment with ascorbic acid alone (Fig. $12 \mathrm{~F}$ ) .

Staining of sections of liver with P.A.S. stain showed normal distribution of glycogen content in the hepatic cells (Fig. 13 A). The 

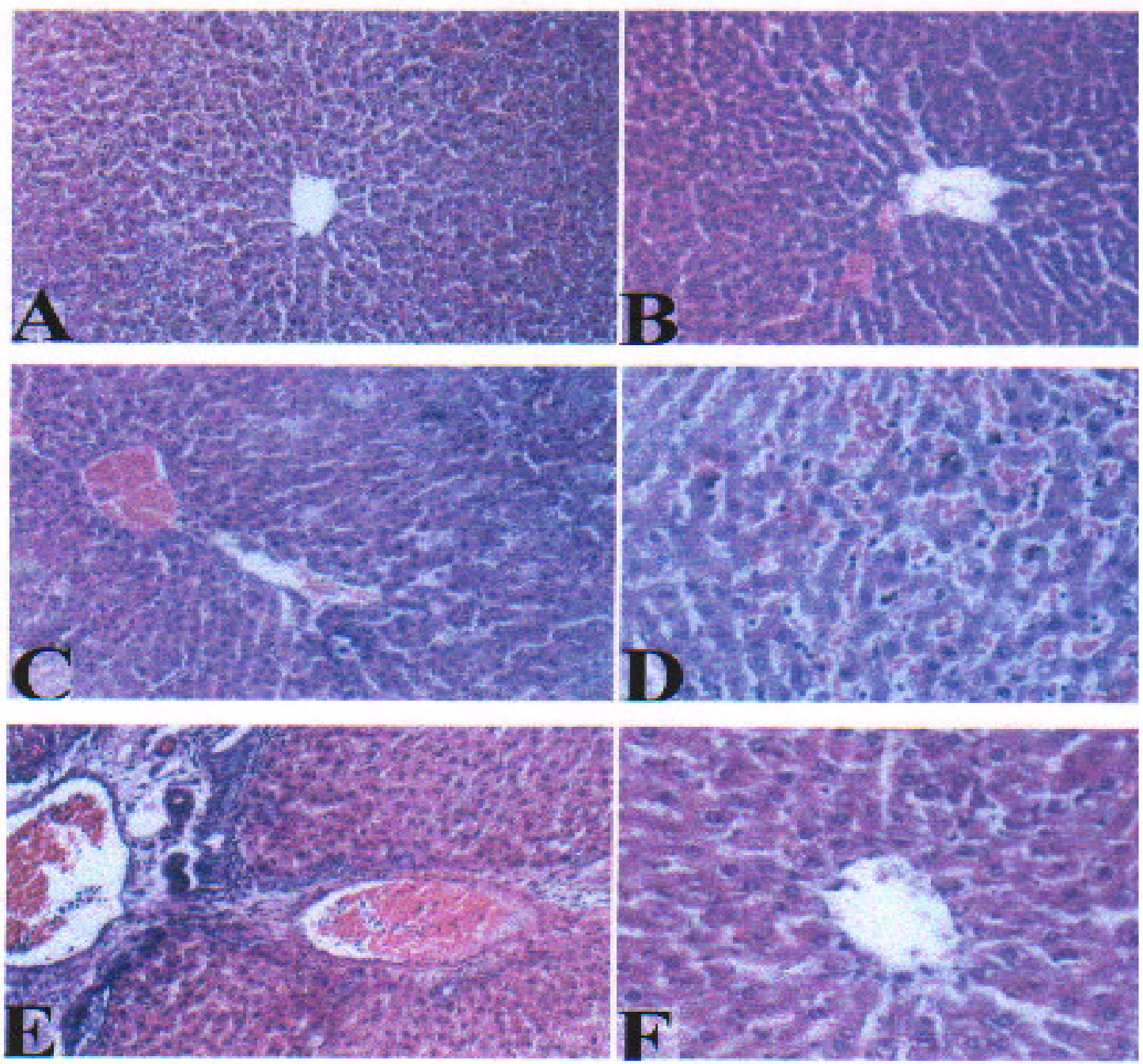

Fig. (12): HX/Eosin Stain

A) A photomicrograph of control liver demonstrating a central vein with radi hepatic cords, ((HX \& E X200).

B) A Photomicrograph of rat liver treated with fenitrothion showing dilated $\mathrm{c}$ vein with hemorrhagic area between hepatic cells (HX \& E X200).

C) A photomicrograph of the previaus group showing vascular dilatatio degeneration in some areas of hepatic cell (HX \& E X200).

D) A Photomicrograph of rat liver treated with fenitrothion plus beta-carc showing a decrease in vascular dilatation \& degeneration of some hepatic plenty of von kupffer cells (HX \& E X200).

E) A Photomicrograph of rat liver treated with fenitrothion plus ascorbic showing vascular dilatation and improvement of degeneration of hepatic (HX \& E X200).

F) A Photomicrograph of rat liver treated with ascorbic acid alone showing a ce vein with radiating hepatic cords (as the control), the same result was with carotene (HX \& E X200). 


\section{Analytical and microscopical studies}

optical density (O.D.) of glycogen in control groups was 0.524 (S.D \pm 0.066 and S.E. 0.038) . Table (9) and Fig. (14) .

After administration of fenitrothion there is depletion of the glycogen content of hepatic cells after staining with P.A.S stain (Fig.13B). The optical density (O.D) of glycogen group was 0.319 (S.D. 0.024, S.E, 0.014) Table (9) and Fig. (14) . Combination of insecticide with beta-carotene causes no improvement but only decrease in glycogen content of hepatic cells with still relative vascular dilatation (Fig. 13 C). The optical density (O.D) of glycogen was 0.262 , S.D $=0.050, \mathrm{~S} . \mathrm{E}=$ 0.029 Table (9) and Fig. (14).

On the other hand combination of the insecticide with ascorbic acid causes more relative improvement or increase in glycogen content of hepatic cells (Fig. 13 D). The optical density (O.D) of glycogen was 0.476, S.D $=0.073$, S.E $=0.042$. Table (9) and Fig. (14). Treatment with beta-carotene alone causes no change in glycogen content of hepatic cells (Fig. 13 E). The optical density (O.D) of glycogen was 0.393 , S.D $=0.060$, S.E 0.034 . Table (9) and Fig. (14) .

The same results were obtained with treatment with ascorbic acid alone (Fig. 13 F). The optical density (O.D) of glycogen was 0.452 S.D $=0.060$, S.E \pm 0.034 . Table (9) and Fig. (14) .

However comparison between the optical density (O.D) in control specimens and specimens received the insecticide revealed a $\mathrm{T}$. value $=0.007$ with a $\mathrm{P}=<0.05$ meaning a significant decrease in glycogen content compared to control group Table (9) .

Also, comparison between the optical density (O.D) in specimens received insecticide and specimens received insecticide with beta-carotene revealed a $\mathrm{T}$. value $=0.157$ with a $\mathrm{P}=<$ 0.05 meaning a significant decrease in glycogen content compared to specimens received insecticide. Comparison between the optical density (O.D) in specimens 

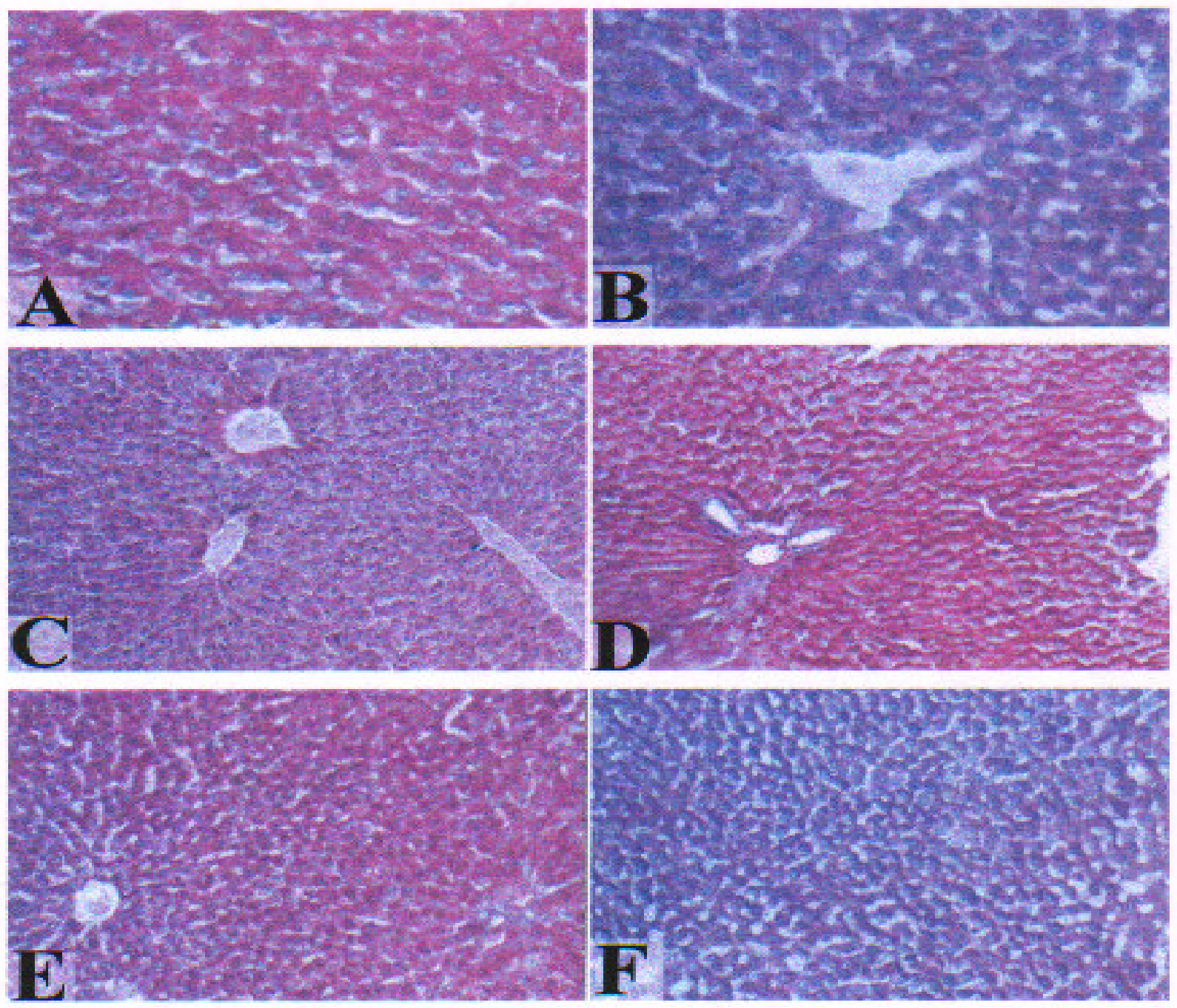

\section{Fig. (13): P.A.S. Stain}

A) A photomicrograph of control liver demonstrating a normal distribution of glycogen content (P.A.S. Stain X200).

B) A Photomicrograph of rat liver treated with fenitrothion showing relative decrease in glycogen content of hepatic cells (P.A.S. Stain X200).

C) A photomicrograph of rat liver treated with fenitrothion plus bete-carotene showing a slight increase in glycogen content and relative vascular dilatation (P.A.S. Stain X200).

D) A Photomicrograph of rat liver treated with fenitrothion plus ascorbic acid showing a relative increase in amount of glycogen in hepatic cells (P.A.S. Stain X200).

E) A Photomicrograph of rat liver treated with beta-carotene alone showing a normal distribution of glycogen content (as control) (P.A.S. Stain X200).

F) A Photomicrograph of rat liver treated with ascorbic acid alone showing the same result of control (P.A.S. Stain X200). 
Table (9): Changes in the glycogen content in the rat's liver under the effect of treatment with fenitrothion alone and combination with ascorbic acid and beta-carotene

\begin{tabular}{|c|c|c|c|c|c|c|}
\hline & Control & Fenitrothion & Inse. + Beta coratene & Insec.+ Ascorbic acid & Beta carotene & Ascorbic acid \\
\hline Sample 1 & 0.532 & 0.324 & 0.253 & 0.433 & 0.425 & 0.430 \\
\hline $\mathbf{2}$ & 0.453 & 0.292 & 0.315 & 0.433 & 0.430 & 0.443 \\
\hline $\mathbf{3}$ & 0.585 & 0.340 & 0.217 & 0.561 & 0.325 & 0.483 \\
\hline Mean & 0.524 & 0.319 & 0.262 & 0.476 & 0.393 & 0.452 \\
\hline S.D & 0.066 & 0.024 & 0.050 & 0.073 & 0.060 & 0.060 \\
\hline S.E. & 0.038 & 0.014 & 0.029 & 0.042 & 0.034 & 0.034 \\
\hline T.value & & $\mathbf{0 . 0 0 7}$ & $\mathbf{0 . 1 5 7}$ & $\mathbf{0 . 0 2 1}$ & $\mathbf{0 . 1 0 1}$ & $\mathbf{0 . 0 7 3}$ \\
\hline P.Value & & Sig.dec.< $\mathbf{0 . 0 5}$ & Sig.dec.< $\mathbf{0 . 0 5}$ & Sig.inc.< $\mathbf{0 . 0 5}$ & Non-Sig. & Non-Sig. \\
\hline
\end{tabular}

Fig. (14) Changes in the glycogen content under the effect of treatment with fenitrothion alone and combination with ascorbic acid and beta-carotene

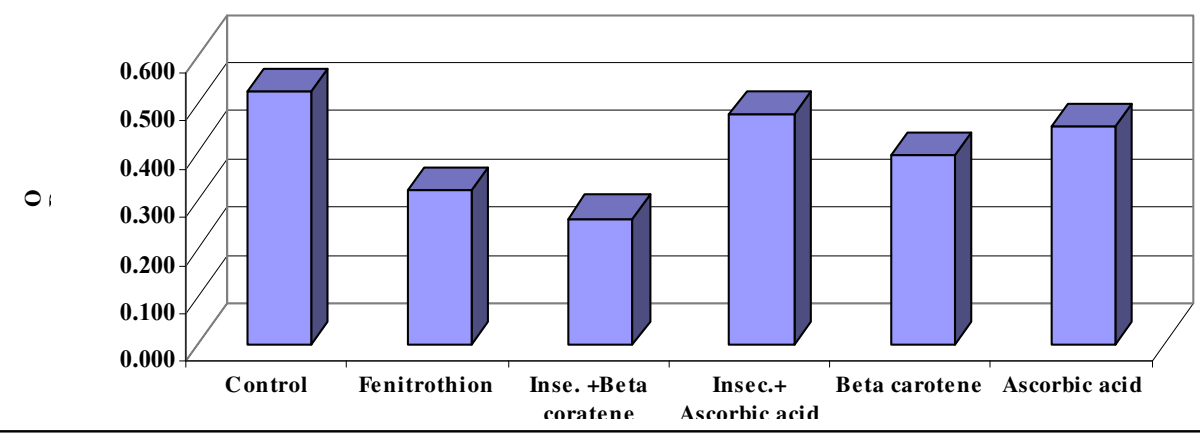

received insecticide and specimens received insecticide with ascorbic acid revealed a $\mathrm{T}$. value $=$ 0.021 and a $P$ value $=<0.05$ meaning a significant increase in glycogen content

Comparison between the optical density (O.D) in control specimens and specimens received beta-carotene revealed a $\mathrm{T}$. value $=0.101$ and a $\mathrm{P}$ value indicating non significant change in glycogen content.

Comparison between the optical density (O.D) in control specimens and specimens received ascorbic acid revealed a $T$ value $=0.073$ and a $P$ value meaning non significant change in glycogen content

Staining control specimens with methyl green pyronin to detect nucleic acid control shows its normal distribution in hepatic cells (Fig. 15 A). However administration of insecticide fenitrothion cause decrease in the nucleic acid content of hepatic cells (Fig. 15 B) .

Combination of the insecticide with beta-carotene causes no improvement and there is still also 
depletion of nucleic acid content of the hepatic cells (Fig. 15 C). However combination of the insecticide with ascorbic acid causes no change in the depleted amount of nucleic acid (Fig. 15 D) .
Administration of beta-carotene alone causes no change in nucleic acid content of hepatic cells compared with control specimens (Fig. 15 E). However, the same results were obtained after administration of ascorbic acid alone (Fig. 15 F) .
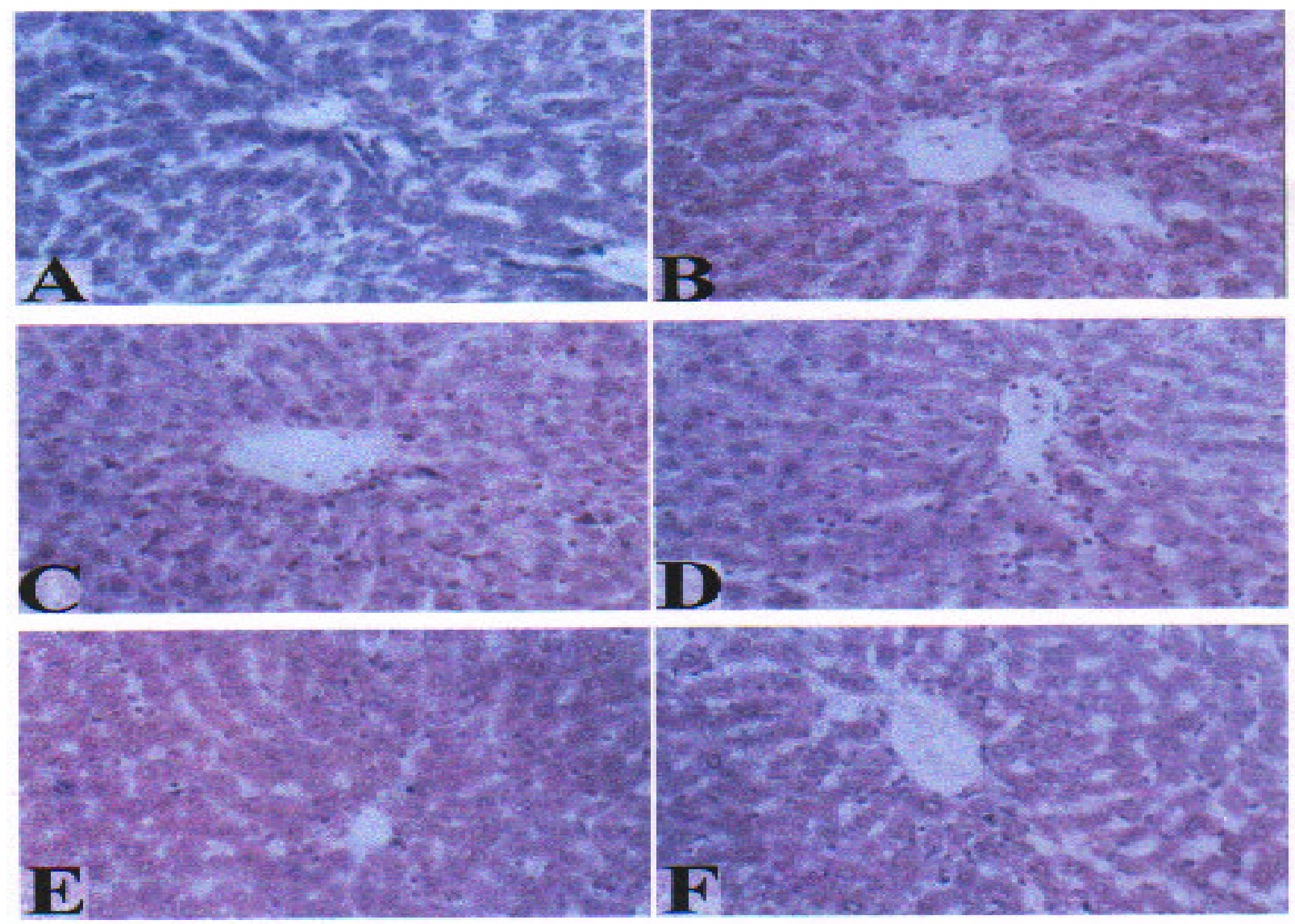

\section{Fig. (15): M.G.P Stain}

A) A photomicrograph of control rat liver demonstrating a normal presence of nuclic acid content in hepatic cells (M.G.P. Stain X250).

B) A Photomicrograph of rat liver treated with fenitrothion showing relative depletion of nuclic acid content in hepatic cells (M.G.P. Stain X250).

C) A photomicrograph of rat liver treated with fenitrothion plus bete-carotene showing a decrease in nuclic acid content in hepatic cells (M.G.P. Stain X250).

D) A Photomicrograph of rat liver treated with fenitrothion phus ascorbic acid showing a decrease in nuclic acid content in hepatic cells (M.G.P. Stain X250).

E) A Photomicrograph of rat liver treated with beta-carotene alone showing a normal nuclic acid content in hepatic cells (as control) (M.G.P. Stain X250).

F) A Photomicrograph of rat liver treated with ascorbic acid alone showing a normal content of nuclic acid in hepatic cells (as control) (M.G.P. Stain X250). 


\section{Analytical and microscopical studies}

\section{Discussion}

Several investigators have been reported that the application of fenitrothion as organophosphorus comp -ound has been used extensively as insecticide and acaricide for control of a wide range of pests [Worthing, 1983 and 1987]. Therefore, human and animals may be subjected to such compound via food, water and air and this could affect their health as demonstrated by Yamanaka et al. (1993). In the present study, the toxicity of fenitrothion was evaluated in female rats as a laboratory animal model and the possible protective effects of certain antioxidants (i.e ascorbic acid and beta- carotine) against this toxicity were also evaluated.

The present results of the estimated biochemical parameters indicated that, ingestion of fenitrothion caused a significant increase in ALT, AST, and AP activities, these results may indicate degenerative changes and hypofunction of liver, Justin et. al, 1991, Gomes et al 1999, and Kadry et al, 2001. The increasing of AP activity may be due to the induction of such enzyme as a response to the remained amounts of fenitrothion and its metabolites which needs more hydrolysis of phosphate bond to be able to eliminate. Furthermore, it is well documented that, the elevation in serum alkaline phosphatase (AP) indicates that there is an impairment of liver function and obstruction of flow (Lykasova and Rabinovich; 1988, Stevens and Galla, 1989). The results also showed that treatment with fenitrothion decreased significantly serum level of AChE, GL and $\mathrm{GSH}$, while, it had insignificant effects on TB and it caused a slight decrease in TP. The inhibitory effects on $\mathrm{AChE}$ was expected, as the organophosphate compounds are anticholinesterase agents such finiding was reported since, 1950's by many investigators [Barber et al 1999, Gome, et al 1999, Nigg and Knaak 2000).

The decreasing effect of fenitrothion on GSH is supported by the fact that glutathion, S.transferase is used in catalyzing the conjugation process of fenitrothion and / or its metabolites with glutathion as starting point of the limination process.

Farthermore, this explanation was in harmony with other results obtained by Motoyame and Dauterman, (1978); Matsumora, 1985; Datta et al (1997); Ecobicon, 1996, and Kadry et al. 2001. The slight increase in TB may be due to the effect of fenitrothion on liver functions [stevens and Gallo 1989; Paulino et al; 1996, and Nabila et al, 2001].

Thus, the present results clearly indicated that fenitrothion has a harmful and stressful influence on liver's functions. Also, Manisha et al, 1999; reported that organophosphates have been shown to produce oxidative stress through the generation of free oxygen radical.

It is of interest to mention that, the treatment of female rats with fenittrothion plus beta-carotene or ascorbic acid didn't cause any significant change in AST and ALT activities. The same result, were sighted in AChE, glucose, TB and TP. Ascorbic acid plus fenitrothion was more efficient in formation of AP than beta-carotene plus fenitrothion. It is important to notice that GSH concentration was increased in female rats after treatment with fenitrothion combined with ascorbic acid and betacarotin, but this was more pronounced 
in the former. This indicated that ascorbic acid was more efficient than beta-carotin in the formation of GSH in liver of female rats. It was suggested that ascorbic acid exert its protective effects by acting as a precurs for GSH, the main low molecular antioxidant and as a free radical scavenger [ Lin- Chun et al 1998, Kang- Soon et al 1998, Skrzydlewska and Farbiszeweski, 1999). These authors reported an increase in glutathione reductase in the liver and GSH, related enzymes in serum and liver. Also, they reported that, ascorbic acid may alleviate oxidative tissue damage by quenching radical as they are produced or aggravate damage by interacting with free meta thions released from damaged cells to accelerate hydroxyl radical production.

Present results also showed that both of betacarotene and ascorbic acid can increase of GSH level in the liver when given alone without insecticide. The protective effects of beta- carotene and ascorbic acid against fenitrothion may be due to the antioxidant actions of GSH [Lawlor and O, Brien 1997, Newholme 1999, and Nabila et al 2001).

Fenitrothion, however, is a greater acetyl choline estrase inhibitor than matathion (Barber et al, 1999). The toxic effect of such insecticide included, Hemorrhage, congestion which can most probobly explained by the toxic effect of the drug on the endothelium of sinusoids and intercellular substance between such cells.

The degenerative effect on the hepatic cells can also explained by the same way with the decrease in the nucleic acid content. Such results are in agreement with those of Nabila et al, 2001, who studied the effect of pyriproxyfen on the liver of female rats and concluded that there was disorganization of hepatic cords with debris from necrotic cells, massive cellular infiltration around the congested vascular and scattered hepatocellular degeneration with individual cell necrosis. Also, Salem et al 1995, on their study on the pathological action of chronic organo phasphrous toxicity concluded, that there was degenrative and necrotic changes in the wall of blood vessels as well as in the liver, lungs, kidneys, intestines and testicles.

Antioxidants such as beta- carotene, however improves some toxic changes specially vaseular changes most probably through their action on the metabolic processes of the endothelial cells and inter cellular substance this was prooved by the work of junqueira et al 1988, on lindane toxicity with morpholigical evidence and hepatic cell damage. On the other hand, there was no improvement of the nucleic acid content with compination with betacarotene and insecticide.

However, the effect of ascorbic acid as a reducing agent can ameliorate the degenerative effect of the insecticide on the metabolic processes of hepatic cells. The work of Kang Soon et al. 1998, prooved that pretre atment with vit.c prevented the pathological changes in the lungs of rats treated with $50 \mathrm{mg} / \mathrm{kg}$ paraquat, also the work of Nabila et al (2001) on the effect of cysteine and green tea on the liver of albina rats treated with pyriproxyfen insectcide may have similar explana tion. She attributed the protective effect of cysteine may be through its action as a precursor for GSH the main low molecular antioxidant and as a free radical scavenger.

On the other hand, there was no improvement of the nucleic acid content 


\section{Analytical and microscopical studies}

with compination of vit. E. and insecticide.

As regards glycogen content in hepatic cells the toxic effect of the insecticide fenitrothion will affect glycogen storage by such cells as was concluded by Justine et al. 1991, Sato and Izumi 1989, They stated that the disturbance that accurred in the carbohydrate metabolism may be secondary reseult of the hepatic damage and tissue, injury which may be responsible for impairment of liver and kidney function due to intoxication with insecticide.

Beta- carotene, however, does not improve the glycogen content when given with fenitrothion on the other hand the content decreased which may indicate a sort, synergestic action between the fenitrahion and betacarotene or ascorbic acid as reducing agent improves the metabolic activity of the hepatic cells so when given with fenitrothion, it caused marked improvement and increase in glycogen content in hepatic cells.

\section{Acknowledgement}

The authers would like to express their hearty appreciation sincere gratitud to professor Dr.Sherif M.Hashim professor of Histology Department of Histology Faculty of Medicine AlAzhar University for his valuable advise , efforts and unlimited help in preparing this work.

\section{References}

1. Barber-D; Correll-L; and Ehrich-M; (1999): Compartive effectiveness of organophosphorus protoxicant activating system in neuroblastoma cells and brain homogenates. Journal - of Toxicology - and Environmental Health. - Part - A. Envir. Health, 57; $1,63-74$.

2. Bradford-M; (1976) : A rapid sensitive method for quantification of microgram quantities of protein vltilizing the principle of protein dye Linding. Anal. Biochem. 72 : $248-254$.

3. Clayden-EC; (1971): Practical section, cutting and staining. Churchill Living stone, E dinburg and London.

4. Concon-JM; (1988): Man made organic chemical food contaminants. In Food Toxicology Contaminants and additives Part B. pp. 1133 1231. Dekker, New York.

5. Datta-C; Gupta-J; Sarker-A; and serqupta-D; (1997): Effects of organophosphorus insecticide phosphamidon on antioxidant defence components of human ergthrocyte and plasma. Irdian J. Exp. Biol. 30 (1) : $65-67$.

6. Do Quy Hai; Varga-SI; and Matkovics-B;

(1997):

Organophosphate effects on antioxidant system of carp (cyprinus carpio) and catfish (Ictalurus nebulosus). Comparative Biochemistry and physiology, c, pharmacology, Toxicology and Endocrinology. 117: 1, $83-88$.

7. Drury-RA; and Wallington-EA; (1980): carletn's techniques $5^{\text {th }}$ ed. Oxford university press oxpord, New York, Toronto 49, 14 - 142.

8. Dwivedi-PD; Das-M; and khanna-SK; (1998): Role of cytochrome P- 450 in quinalphos toxicity: effect on hepatic and brain antioxidant enzymes in rats. Food and chemical Toxicology 36: 5, 437 $-444$. 
9. Ecobicon-DJ; (1996): Toxic effects of pesticided in casasett and Doulis Toxicology the Basic science of poisons. $5^{\text {th }}$ edition, C.D. Klaasser (ed) Mccraw- Hill press, New York pp. $662-663$.

10. Ellman-G; Courtney-KD; Ahdrs-V; and Featherstone-RM; (1961) : Anew and rapid colorimitric determination of acetylcholinesterase activity. Biochem. Pharmacol. 7: 88 -95 .

11. FAO / WHO; (1974): Toxicological evaluation of some food colors, Enzymes, Flavor enhancers, thichening agents and certain other food additives, WHO Food Additive series No. 6, World Health organization, Geneva, Switzerland.

12. FAO / WHO; (1981): Report of the joint FAO / WHO Expert Connitte on Food Additives. WHO Technical Report Series No.710, World Health Organization, Geneva, Switzer Land.

13. Finney-DJ; (1952): Statistical Metods in Biological Assay. Charles Griffin and Co. Ltd London P. 524 - 530 .

14. Geetanjali-D; Rita-P; and ReddyPP; (1993): Effect of ascorbic acid in the detoxification of the insecticide dimethoate in the bone marrow erthrocytes of mice. Food and chemical Toxicology. 31: 6, $435-437$.

15. Gomes-J; Dawodu-AH; Lioyd-O; Revitt-DM; and Anilal-SV; (1999): Hepatic injury and disturbed amino acid metabolism in mice following prolonged exposure to organophosphorus pesticides. Human and Experimental Toxicology. 18; 1, $33-37$.

16. Habig-WH; Pabst-MS; and Jakoby-WB; (1974): Glutathione -
S. trans ferase. The first enzymatic step in mercapturic acid formation

J. Biol. Chem. 249: 7130 - 3139.

17. Hai-DO; Varga-IS; and Matkovics-B; (1995): Effect of an organophosphate on the antioxidant system of fish tissues. Acta, Biologica- Hungarica, 46: 1, 39 - 50.

18. Junqueira-VBC; Simizu-K; Halsema-L-Van; Koch-OR; Barros-SBM; Videla-LA; VanHalsema-L; (1988): Lindaneinduced oxidative stress. 1- Time course of chanqes in hepatic microsomal parameters, antioxidant enzymes, Lipid peroxidative indices and morphological characteristics. Departamento de Bioquimica, instituto de Quimica, Universidade de sao Paulo, 01498, Po Box 20780, Sao Paulo, Brazil- Xenobiotica, 18:11, 1297 - 1304.

19. Justin-WB; ArchibaddavidNN; Balasubra-MM; and Dwewan -Mis; (1991): Procaine and Lidocaine as adjuncts to thiopentone sodium anesthesia in canine. Indian, j. Vet. Surg., 12 (1): $1-6$.

20. Kadry-MW; Bayoumi-A E; Mohamed-KA; and Ekram-F; Hashim (2001): Acute intoxication and coefficient of distribution of fenitrothion in female rat tissues. Bull. Fac. Pharm. Cairo univ. Vol. 39, No (2): 147 - 154.

21. Kang-Soon Ah; Jang Yeonjin; Park-Hyoung sup; Kang-SA; Jang-Yj; and Park-HS; (1998): In vivo dual effects of vitamine $\mathrm{C}$ on paraquat- induced lung damage: dependence on released metals from the damaged tissue. Free radical Research, 28: 1, 93 - 107.

22. Lawlor-SM; and O-BrienNM; (1997): Modulation of paraquat 
toxicity by beta-carotene at low oxygen partial pressure in chicken embryo fibroblasts. British-Journalof-Nutrition, 77: 1, $133-140$.

23. Leonard-EG; (1983): Under Standing Medical Statistics.William Heinemann Medical Books Limited, London.

24. Lin-ChunChing, Yen Ming Hong, Lo-Tsae shiuan, Lin-Jer Min, Ling CC; Yen. MH, Lo-TS; and Lin-J M; (1998): Evaluation of the hepatoprotective and antioxidant activity of Boehmeria nivea var. nivea and $B$. nivea var. Tenacissima. Journal-of Ethnopharmacology. 60: $1,9-17$.

25. Lukaszewicz-Hussain-A; and Moniuszko-Jakoniuk-J; (1999): Effect of acute intoxication with chlorfenvinphos on activity of antioxidant enzymes and concentration of malondialdhyde in rats. Roczniki PanstwowegoZakladu- Higieny, 50: 3, 307 - 311 .

26. Lykasova-IA; Rabinovich-MI; (1988): Effect of kelthane (dicofol) on activity of some serum enzymes in fowls . Veterinariya, - Moscow No. 4, $59-61$.

27. Manisha-Kale; NishaRathore; Susan-John; DeepakBhatnagar; kale-M; Rathore-N; and John-S; Bhatnagar-D; (1999): Lipid peroxidation and antioxidant enzymes in rat tissues in pyrethroid toxicity: Possible involvement of reactive oxygen species. Journal-ofNutritional- and Environmental Medicine, 9: 1, 37-46.

28. Matsumora-F; (1985): Metabolism of insecticides by animels and plants. In: Toxicology of Insecticides $\quad 2^{\text {nd }}$ edition, $F$. Matsumora (ed). Plenum press. New. York. pp.213.
29. Minakata-K; Suzuki-O; Ohishi-S; Hayashi-I; Saito-S; and Harada-N; (1995): Acute - phase reactant proteins and antioxidants in rats intoxicated chronically with paraqat. Journal- of - Toxicologyand Environmental - Health. 44: 1,29-41.

30. Motoyama-N; and Deuterman-W; (1978): Multiple forms of rat liver glutathionras S. transferase specificity for conjugation of O- alkyl and O- aryl groups of organophorus insecticides. J. Agric Food chem. 26 (6): 1296 1301.

31. Nabila-S; Hassan, kadry-M; Weshahy; Hannaa-H; Ahmed and Mosaad-A; AbdEl-Wahhab; (2001): Effects of Antioxidands on oxidative stress of pyriproxyfen in female rats. Medical Journal - of Cairo University vol. 69, No 1 March: 79-90.

32. Newholme-E; (1999): Application of methionine-free nutrition as anticancer treatment. Nutrition, 15 (5): 422 - 424.

33. Nigg-HN; and Knaak-JB; (2000): Blood Cholinesterase as human biomarkers of organophosphorus pesticid exposure. Rev. Environ. Contan. Toxicol. 163: 29-111.

34. Paulino-CA; Guerra-JL; Qliveira-GH; and Parlermo-NetoJ; (1996): Acutes, subchronic and chronic $2,4 \mathrm{~d}$ : chlorophenoxy acetic acid $(2,4-D)$ intoxication in rats Vet. Human Toxical. 38 (5): 348352.

35. Pearlman-FC; and Lee-RY; (1971): Detection and measurment of total bilirubin in serum with use of surfactants as solubilizing agents. Clin. Chem. 20: 447-453. 
36. Pearse-AG; E; (1968): Histochemistry Theoretical and Applied. Churchill, Livingstone, London Vol. I, $3^{\text {rd }}$ ed.

37. Powell-ME; and Smith-MJH; (1954): The determination of serum acid and alkaline phosphatase activity with 4- aminoantipyrine (A.AP.). J. clin. Path. 7: 245-248.

38. Reitman-S; and Frankle-S; (1957): colorimetric method for aetermination of aspartate and alamine transferase. Amer. J. Clin. Path. 28: 56- 63.

39. Salem-HA; Mahmoud-AZ; Nafady-AA; and El-Ghaffar SKAbd (1995): Experimental Pathological studies on the effect of some organophosphorus Compound; with the use of vitamins SD3E as prophylaxis. Proceedings of the third scientific congress Egyptian Society for Cattle Diseases. Assiut Egypt volum 2. 312-322.

40. Sato-C; and Izumi-N; (1989): Mechanism of increased adminstration of caffeine in the rat. Journal Pharmacology Exp. Ther. 248 (3): 1243-1247.

41. Sen-CK; (1999): Glutathione homeostasis in response to exertraining and nutritional supplements, Mol. Cell Biochem., 196 (1-2): 31-42.

42. Shrzydlewska-E; and

Farbiszewski-R; (1999): Protective effect of N- acetylcystein on reduced glutathione, reduced gluathione related enzymes and lipid peroxidation in methanol intoxication. Drug Alcohol. Depend., 57 (1): 61-67.
43. Stevens-KR; and Gallo-MA; (1989): Practical considerations in the conduct of chronic toxicity studies. In Principles and Methods of toxicology A.W. Nayes (ed). Reven Press, Ltd., New York, PP. 248.

44. Stevenson-DE; Kehrer-JP; kolaja-KL; Walborg-EF Jr; and Klaunig-JE; (1995): Effect of dietary antioxidants on dieldrininduced hepatotoxicity in mice. Toxicology Letters. 75: 1-3, $111-$ 183.

45. Trinder-P; (1969): Enzymatic colrimetric method for determination of glucose. A . clin. Biochem. 6:24.

46. Worthing-CR; (1983): The pesticide Manual; A World compendium seventh Edition. Published by the British Crop Protection Council.

47. Worthing-CR; (1987): The Pesticide - Manual: A World compendium eighth edition Published by the British Crop Protection Council.

48. Yamanaka-S; Yashide-M; Yamamura-Y; Nishimura-M; and Takaesu-Y; (1993): A study on acute organophosphorus poisoning changes in the activity and isozyme pattern of serum cholinesterase in human poisoning. Nippon Eiseigaku Zasshi 48 (5): 955-965. 


\section{Analytical and microscopical studies}

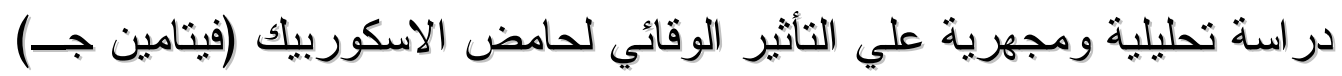
و البيتاكاروتين ضد سميه مبيد الفينيتروثيون علي كبد إناث الفئران البيضاء

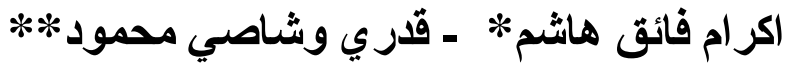 قسم وقاية النبات}

كلية الزراعة -فرع الفيوم-جامعة القاهرة* - كلية الزراعة-جامعة عين شمستهن

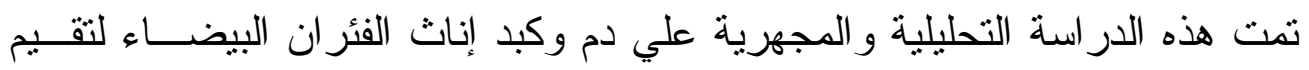

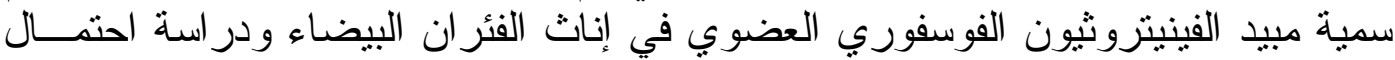

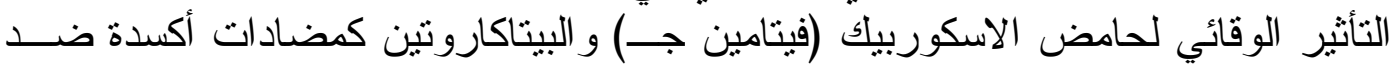

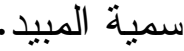

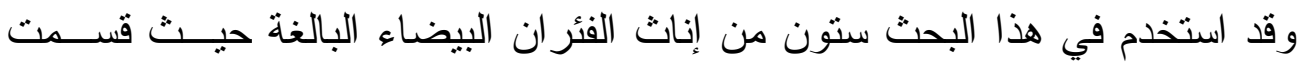

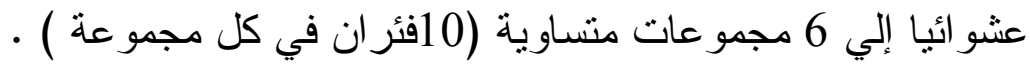
المجموعة الأولى :استخدمت كمقارنة .

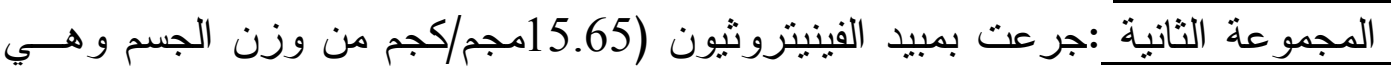

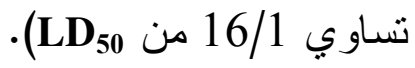

المجموعة الثالثة : جرعت بالمبيد حامض الاسكوربيك(16.65 منجماكم/كجم من وزن الجسم

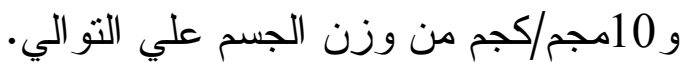

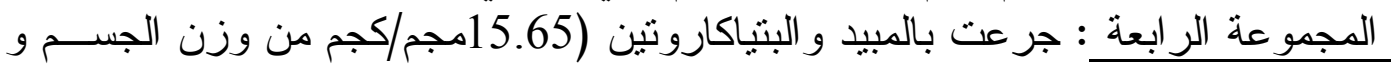

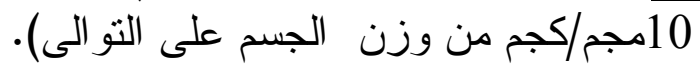

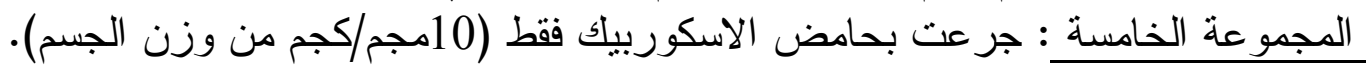

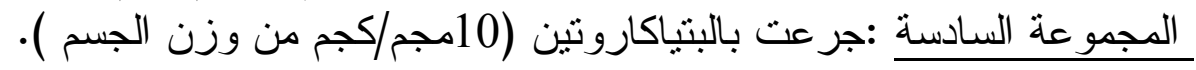

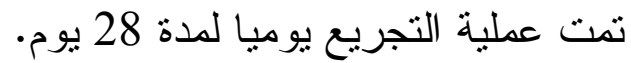

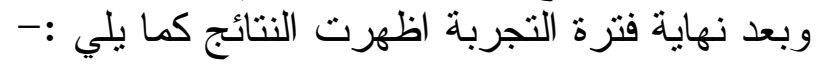

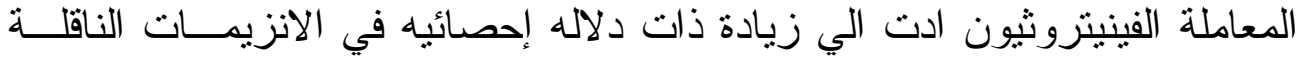

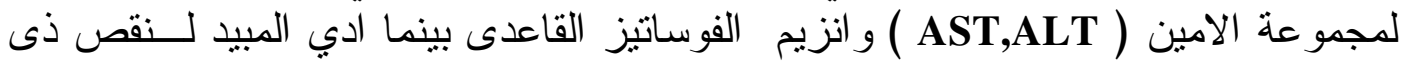

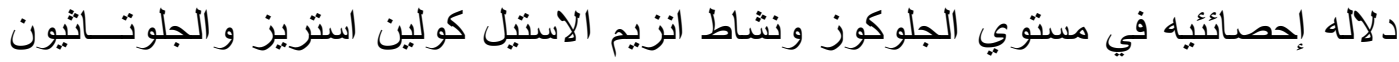

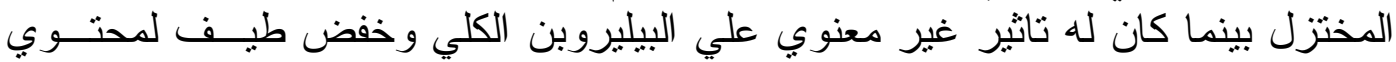

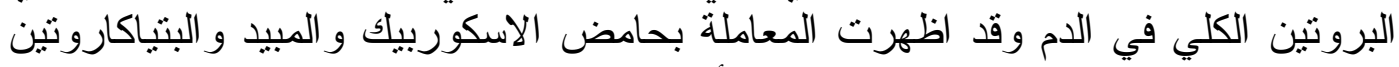

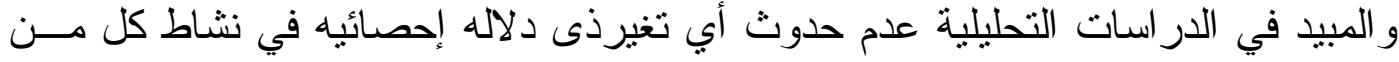

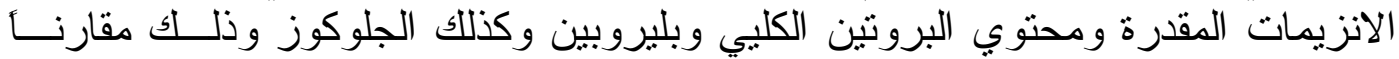

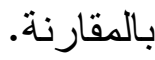


وقد بينت الدر اسات الهستولوجية علي عينات من كبد إناث الفئر ان باستخدام صبغة

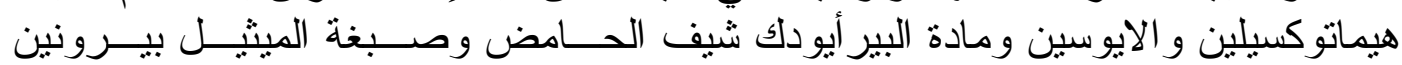

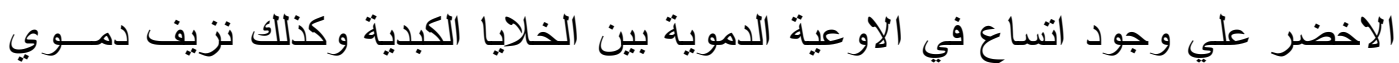

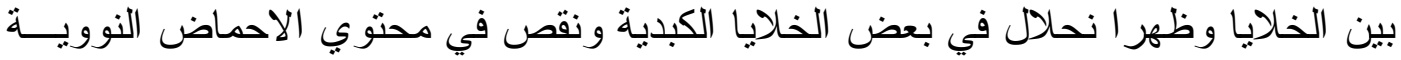

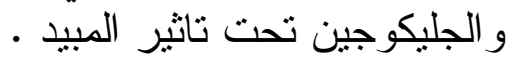
و ادت المعامله بالمبيد مع حامض المبيد الاسكوربيك و المبيد مع البتياكاروتين الي تحسين

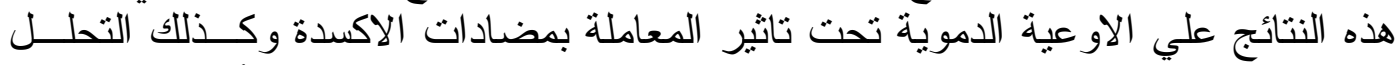

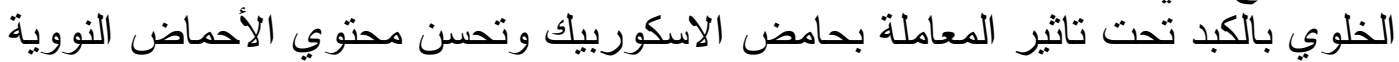

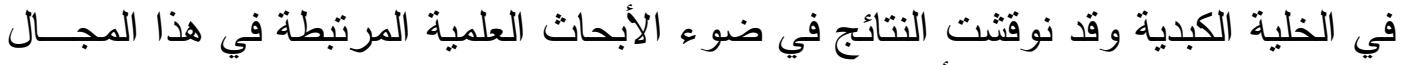

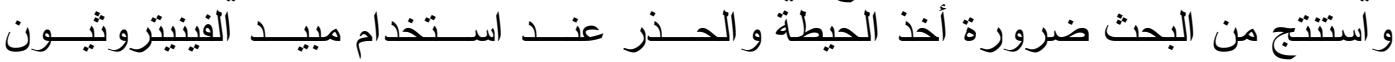
حصوصا عند استعمال جرعات عالية منه ويمكن باستخدام مضادات الاكسدة التقليل مــن

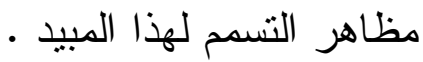

